\title{
Analyzing the Effectiveness of Environmental Policies to Reduce Citizens' Exposure to Air Pollution
}

\section{Leticia Abarca Velencoso}

Carlos III of Madrid University, School of International Studies and Political Science, Madrid, Spain https://doi.org/10.38126/ISPG190112

Corresponding author: l.abarca.velencoso@gmail.com

Keywords: citizen exposure to air pollution; PM2.5; environmental policy; OECD; innovation; feed-in tariffs; energy; green fiscal policy.

Executive summary: Exposure to air pollution causes significant damage to health, which leads to large economic and social welfare losses. As a result, the urgency of reducing PM2.5 levels, the main indicator of citizens' exposure to air pollution, is gaining importance. PM2.5 is a mixture of solid and liquid particles, smaller than 2.5 micrometers, that are suspended in the air. Most literature on the analysis of environmental policies is measured exclusively in $\mathrm{CO}^{2}$ targets, excluding other measurements of air pollution, and failing to analyze the effectiveness of those policies in terms of citizen exposure to air pollution. This paper reviews relevant literature and offers approaches to reducing citizens' exposure to air pollution by comparing an Ordinary Least Square (OLS) analysis on the effectiveness of environmental policies to reduce PM2.5 emissions in thirty-three OECD countries between 1990 and 2012, grouped into R\&D investment policies, economic incentive policies, and fiscal policies. Moreover, this article presents evidence that not all environmental policies are equally effective at minimizing PM2.5 and highlights successful innovation and economic incentive policies that create opportunities to invest or develop alternative forms of production. In summary, state investment policies in R\&D show positive but limited results, university-industry research partnerships show highly positive indirect effects on PM2.5 levels; fiscal policies have counterproductive effects, and among economic incentive policies, only feed-in tariffs present an actual opportunity to reduce PM2.5 emissions. The empirical discoveries presented here diversify the research on environmental policies and have profound political implications. Therefore, this study provides a useful tool for environmental policymakers that aim to cut air pollution levels and reduce the human, social and economic consequences.

\section{Introduction}

\section{i. The importance of PM2.5-focus studies}

Particulate matter of less than $2.5 \mu \mathrm{m}$, commonly known as PM2.5, is a mixture of solid particles and liquid components that can be found in polluted air. According to a study published by the Committee on the Medical Effects of Air Pollutants (COMEAP) (2010), a public policy aimed at reducing the levels of citizens' exposure to air pollution (PM2.5) by 1 $\mu \mathrm{g} / \mathrm{m}^{3}$ would save four million lives for a population of sixty-five million, comparable to that of the population of the United Kingdom. Additionally, similar studies link the direct effects of pollution on human health with costs of up to 9\% of GDP in some of the Organization for Economic Co-operation and Development (OECD) countries (OECD 2020). These studies highlight the importance of reducing citizens' exposure to air pollution, in both health and socioeconomic terms. Unfortunately, most academic literature has been aimed at reducing levels of $\mathrm{CO}^{2}$ or other greenhouse gases which are responsible only for climate change, while relegating studies on the effects of pollution on our health and our society to a 
position of inferiority. This lack of attention has led to the proliferation of research on the effects of carbon-oriented public policies and a shortage of studies on the effects of environmental policies when dealing with people exposed to PM2.5. In order to bridge this gap, this work aims at investigating the effectiveness of public policies to reduce the direct exposure of citizens to pollution, avoiding the high costs in public health and social welfare that it entails.

Given the scarcity of studies based on PM2.5, literature of reference focuses on those who study $\mathrm{CO}^{2}$. This literature is useful because PM2.5 and $\mathrm{CO}^{2}$ come from the same sources (DEFRA 2013; Ashmore 2013; Gale et al. 2021), but more specific literature is needed because they are generated in different ways. Emissions of $\mathrm{CO}^{2}$ and PM2.5 arise from several sources, mainly fossil fuel combustion in the power generation, industrial, residential, agricultural and transport sectors. The difference in their production is that, while $\mathrm{CO}^{2}$ is a pollutant gas itself, PM2.5 is constituted by several liquid and solid components emitted by those industries in different quantities. Consequently, even if the general sources are the same, the chemical processes associated with their emission produce the several components of PM2.5 in different quantities, altering the final proportion of PM2.5 emissions in comparison with $\mathrm{CO}^{2}$ (Table 1).

As a consequence, the same environmental policies can therefore be applied to reduce both, but the overall effect of these policies will achieve different results-the classic $\mathrm{CO}^{2}$ reduction policies do not always show the same outcomes in carbon $^{1}$ reduction than in microparticles reduction. Consequently, there is a need for differentiated studies on the effectiveness of these policies.

\section{ii. Purpose and methodology of this study}

This work raises the question of whether environmental policies are useful for reducing citizens' exposure to air pollution, and which of them are more effective. The investigation focuses on

\footnotetext{
${ }^{1}$ This paper uses alternatively the words carbon to refer to $\mathrm{CO}^{2}$ and microparticles to refer to PM2.5.
}

three policies: 1) policies of investment on innovation and $R \& D, 2$ ) policies of economic incentives for the use of clean and efficient energy, and 3) fiscal policies that disincentives the use of non-clean energy resources. This work suggests that while investment in R\&D and economic incentive policies can help reduce citizens' exposure to air pollution, fiscal policy fails to reduce the PM2.5 levels and may even increase them.

To test these hypotheses, thirty-three OECD countries from the period 1990-2012 are analyzed, where citizens' exposure to air pollution (expressed as PM2.5) is the dependent variable; and several environmental policies including investment in $R \& D$, University-Industry collaboration, taxes and limitations on emissions, and energy efficiency quotas and certificates, are the independent variables. Data is drawn from the OECD and World Bank datasets. Finally, the statistical analysis will be carried out using an OLS model.

\section{iii. Results}

This study shows that R\&D investment policies help to reduce citizens' exposure to air pollution while fiscal policies increase it. Furthermore, it shows that economic incentive policies display mixed results: some, such as feed-in tariffs, are quite effective in reducing PM2.5 emissions, while others, such as energy efficiency incentives, have the opposite effect.

\section{iv. Structure}

This paper is divided into the following sections: first, a review of the literature covering previous studies on the effects of environmental policies on emissions. Secondly, the theoretical framework of reference and the proposed hypotheses. Thirdly, the description of the research methodology, the various variables and their sources will be carried out, followed by the results. Finally, the conclusions summarize actionable steps for policymakers.

\section{Literature Review}

Which environmental policies are most effective in reducing citizens' exposure to air pollution? The literature on the relationship between public policy and polluting emissions has addressed this question in different ways, although it has focused mostly on the study of carbon emissions. As a result, most of 
the literature presented below revolves around $\mathrm{CO}^{2}$ emissions but given the chemical processes from which PM2.5 results, previous literature serves as a framework for understanding the effectiveness of environmental measures ${ }^{2}$.

Literature about environmental policies has usually had the same aim, that is to understand which policies are best suited to prevent polluting emissions and their consequences (Alvarez-Herránz et al. 2017; Balsalobre et al. 2015; Bosetti et al. 2009; Fernández et al. 2018; Fischer and Newell 2008; Grafton et al. 2014; Jaffe and Palmer 1997; Popp 2006; Schneider and Goulder 1997; Gerlagh and van der Zwaan 2006). In general, researchers have sought to answer those questions about policy effectiveness in reducing emissions through two main argumentative threads. The first focuses on the effectiveness of technological change and government spending on R\&D to reduce polluting emissions, while the second considers energy efficiency and renewable energy, together with fiscal policy, as the main policies for achieving the reduction of emissions.

\section{i. Relationship between polluting emissions and $R \& D$ investment.}

Technological development and innovation are of great importance in economic and political measures to combat climate change and support sustainable development, although quantitative studies are still scarce (Fernández et al. 2018) and authors have not reached a widespread agreement on this matter.

Previous researchers have focused on whether to invest in technology and innovation is an efficient mechanism to reduce polluting emissions. Some authors have defended the effectiveness of these innovation policies in reducing emissions, motivated mainly by the increasing effect of innovation on process efficiency and in the reduction of resources needed. In this line, authors including Balsalobre et al. (2015) investigated the effect of public expenditure on $R \& D$ on energy sectors and their

\footnotetext{
${ }^{2}$ See theoretical framework for a deeper explanation of the relationship between $\mathrm{CO}^{2}$ and PM2.5 in their creation and mitigation, and therefore the adequacy of environmental policies to reduce both.
}

implications in twenty-eight OECD countries and found that investment on energy related innovation had a reducing effect on both energy waste and greenhouse emissions. Alvarez-Herránz et al. (2017) conducted a similar study on the effects of governmental spending in innovation on air pollution levels in seventeen OECD countries and found a negative relationship between pollution and green innovation, especially when innovation focused on energy efficiency. Later, similar results were found by Fernández et al. (2018) in an investigation of the effect of innovation on the emissions of $\mathrm{CO}^{2}$ in European countries.

Other authors have emphasized the importance of innovation by alternative mechanisms. Popp (2006) found that public investments in environmental R\&D produce a drop in emissions because it fosters induced innovation. Induced innovation is understood as a "for-profit investment that responds in the direction of relative prices" (OECD, 2009). That is, as environmental policy makes some inputs more expensive than others, it encourages innovation in some sectors beneficial to the State, as it can be green or resource-efficient technology (OECD, 2009). Similarly, Bosetti et al. (2009) argued that the technological innovations resulting from $\mathrm{R} \& \mathrm{D}$, future climate change mitigation costs and their consequences would be much lower, even if these low long-term costs are associated with increased costs in the short to medium term. In addition, he added that public investment in the development of innovation strategies could be efficient for those governments that are unwilling to impose direct taxes or costs on the most polluting companies, so they could be an effective alternative policy to reduce bioclimatic degradation (Bosetti et al. 2009).

Interestingly, other studies showed opposite results and highlighted the ineffectiveness of innovation investment to reduce pollution. Garrone and Guilli (2010) studied the impact of public investments in green innovation on emissions in thirteen developed countries and their research concluded that these investments had a positive effect on energy efficiency, but that this was not represented in a reduction of $\mathrm{CO}^{2}$ emissions. Similar results were 
found by Cheng et al. (2017) in research conducted in China.

However, some authors have claimed that even if innovation policies could facilitate the creation of new technologies with an ecological nature and consequently reduce emissions, this mechanism is nullified as it does not produce incentives for the collaboration and renovation of companies to innovate or adopt those technologies. This type of technology presents market failures ${ }^{3}$, as the positive externalities mean it is difficult to capture economic value. As a result, several authors recognized that, although innovation plays an important role in emissions reduction, governments need to establish regulations on energy consumption and emissions to make it effective (Das et al. 2015; Bilgili et al. 2017; and Korak and Ulucak 2019). Therefore, these authors found that R\&D policies have a conditional effectiveness regarding other policies, as fiscal or economic incentives.

Supporting this last argument, Fischer and Newell (2008) developed an empirical model that demonstrates government investment in clean technologies is only effective if there is also a system of incentives for industry adoption. For example, Bosetti et al. (2009) showed that R\&D investments are not sufficient to stabilize $\mathrm{CO}^{2}$ emissions, but that emissions taxes were necessary for their effectiveness.

ii. Relationship between polluting emissions and economic and fiscal measures.

Regarding this second approach, scholars focus on the effectiveness of economic incentives and constraints to reduce emissions. (Hart 2008; Schneider and Goulder 1997).

One school of thought suggests that economic incentives and fiscal policies are effective to reduce emissions because of two mechanisms: first, by increasing innovation (Goulder and Mathai 2000; Heyes and Kapur 2011; Lanjouw and Mody 1996) and second, because they lead to a direct reduction

\footnotetext{
${ }^{3}$ For further information on the market failures of environmental technology, see Goulder (2002), Jaffe et al. (2004), and Newell (2007).
}

in polluting gases by incentivizing or disincentivizing the use of certain resources. In any case, the literature has not reached agreement on the effectiveness of innovation policies.

Among the authors who argue that economic and fiscal measures help to reduce emissions (Lanjouw and Mody 1996; Jaffe and Palmer 1997; Goulder and Mathai 2000; Popp 2006; Johnstone and Hascic 2009) we can find various arguments. Firstly, Johnstone and Hascic (2009) argued that, since markets normally fail to account for the actual value of environmental resources, the opportunity cost of these resources is largely a consequence of government taxation and incentives. Therefore, a higher opportunity cost produced by taxes or limitations will produce strong incentives to reduce emissions. Similarly, Lanjouw and Mody (1996), using the idea of induced innovation, demonstrated that the costs associated with pollution imposed by governments at the macroeconomic level led to an increase in the number of patents and therefore, to greener technologies and lower emission levels. Goulder and Mathai (2000) studied the different carbon reduction policies in several governments and found there are two main effects of induced innovation: firstly, the marginal cost of reducing environmental footprint is lower, so the reduced optimal amount is increased; and secondly, it also increases today's marginal cost relative to that of the future, as reduction costs will still be lower and environmental protection will have improved significantly.

In the same vein, Jaffe and Palmer (1997) and Popp (2006) suggest that economic incentive policies were proven to have a significant positive impact on innovation and subsequent environmental protection. Regulation by means of renewable energy labels or "feed-in-tariffs"4 encourages private investment in innovative processes and technologies both domestically and internationally. In addition, the literature demonstrates that government expenditure may help offset the lack of investment in environmentally positive technology sectors, given the market problems presented by them (OECD

\footnotetext{
${ }^{4}$ Feed-in tariffs meaning that the price of electricity is guaranteed for producers for twenty years.
} 
2010). Similarly, a common critique of these proposals is that most of them have been developed theoretically but have not been tested practically.

Following these criticisms, some authors have suggested that, in practical terms, economics and fiscal incentives are not effective in reducing emissions and may even lead to an increase in pollution levels. Grafton et al. (2014) examined the effects of subsidies on biodiesel and technological production on $\mathrm{CO}^{2}$ emissions in the United States and found out that these subsidies were followed by an increase in emissions levels as well as an increase in the consumption of fossil fuels. They named this phenomenon the "rebound effect", which occurs when tax incentives have no effect on reducing energy consumption due to lower energy costs associated with subsidies to renewable energy sources. According to the authors, this phenomenon may indicate that only regulation through subsidies on renewable energy and technology fails to have a significant effect on emission levels (Grafton et al. 2014). Similarly, Hart (2008) showed that it is not effective to impose taxes on emissions that exceed the budget needed to counteract those emissions because this may trigger disincentives to implement new technologies. Later, Bossetti et al. (2009) empirically demonstrated that economic and fiscal incentive policies that focus on induced innovation are not sufficient to stabilize greenhouse gas levels by themselves and need to be compensated with parallel policies.

Finally, by combining these previous reasonings, some authors have focused on conducting comparative studies to identify policies that are most effective and, especially, the combinations of policies that seem to be more successful, although there is still no consensus. Popp studied the long-term effects of coal taxes and R\&D subsidies and found that, in the long term, the combination of $R \& D$ and green taxes policies produced better results than when implementing the policies independently (Popp 2006). In any case, according to Popp (2006), $95 \%$ of the total decrease of emissions produced by environmental regulation was due to green taxes. This result differed from previous theories that rejected the effectiveness of taxes in reducing emissions, including Hart (2008)'s theories.
In the same line, Fischer and Newell analyzed the effect of several policies on reducing $\mathrm{CO}^{2}$ emissions, such as policies to promote innovation, renewable energy, and technological renewal. Their study concluded that while policy effectiveness depends on national environmental parameters and targets, the most effective policy is the imposition of emissions prices, followed by technological performance on emissions, fossil fuel taxes and renewable energy subsidies, and lastly, R\&D investment (Fisher and Newell 2008). In a similar study, Gerlagh and van der Zwaan (2006) found that investment and innovation policies were the cheapest policy to implement to stabilize $\mathrm{CO}^{2}$ levels, although this study did not deal with effectiveness itself, but with efficiency. Because of this, Schneider and Goulder (1997) argued that, although it was cheaper, technology subsidies alone have little impact on improving emissions unless they are accompanied by fiscal policies or economic incentives that directly attack the negative externalities of industrial production.

The literature review shows that among the studies that seek to answer which environmental policies are more effective to reduce emissions, the scholars have not reached an agreement. Both approaches, focus on the effectiveness of innovation policies and focus on fiscal and economic incentives policies, have supporters and detractors. Furthermore, since this field of research is very recent, many studies are only theoretical, and others are very limited due to the lack of data. But the main gap within the literature, as we have previously said, is that it approaches emission reduction from a carbon-centered perspective.

Most studies focus on air pollution through $\mathrm{CO}^{2}$ emissions, although in scientific terms these only account for a small part of polluting gas emissions and have no direct effects on citizens, as other pollutants do. There is a need to approach emissions reduction studies based on other objectives-not just related to global warming, but to health effects as well. This can be done by testing the effects of those traditional environmental policies in PM2.5 emissions levels. It would allow us to understand better how environmental policies are dealing with the overall problem of pollution and how these policies can be effectively implemented to reduce the 
health-related problems associated with pollution in addition to responding to climate change.

\section{Theoretical Framework}

\section{i. Importance of the investigation}

Citizens' exposure to air pollution is understood as the exposure of citizens to polluting emissions that have direct harmful effects on their health (COMEAP 2010). Although several gases have detrimental health effects, the main relationship between medical problems and polluting emissions revolves around microparticles PM2.5. These types of particles are a mixture between solid particles and liquid components that can be found in the polluted air, and are mainly a consequence of industry, energy, agricultural production, and road transport (DEFRA 2013). Inhalation of such particles for long periods of time lead to increased health damage, such as cardiovascular, respiratory, allergic, or carcinogenic diseases (Harrison et al. 2010).

There are two fundamental reasons that underlie the importance for this study: 1) the necessity of measuring the effectiveness of environmental policies with an microparticles-centered approach due to the lack of similarity with $\mathrm{CO}^{2}$ production and 2) the urgence of designing effective public policies for reducing citizens' exposure to air pollution.

In the first place, the sources of microparticles and carbon emissions are the same ones (Table 1), but PM2.5 is, in part, created by numerous chemical and physical processes that cause it to be emitted in different levels and with variable compositions, which in turn means that environmental policies to reduce them may show different results according to the approach taken. Most $\mathrm{CO}^{2}$ emissions are a consequence of the use of fossil fuels, industrial production and the change in land use, while PM2.5 are formed by two different mechanisms: ${ }^{5}$ firstly, through primary sources as $\mathrm{C}^{2}$, resulting from direct emissions of road transport, electrical and agricultural energy and industry; and secondly, through secondary sources, that are caused by the chemical and physical transformation of other gases that can be found in the atmosphere as a result of other human processes, such as nitrogen dioxide, ammonia, sulfates and nitrates, among others (DEFRA, 2013). This secondary process of creation makes PM2.5 more volatile since it depends on the quantity of pollutants and chemical and physical reactions that it supports. Consequently, the levels of $\mathrm{CO}^{2}$ and PM2.5 released in the atmosphere by each human activity are not equal nor directly related. Therefore, $\mathrm{CO}^{2}$ and PM2.5 emissions, as produced in different quantities, behave differently in terms of remission policies. Consequently, previous studies on policies for emission reduction may not be extrapolated without producing biased results.

Secondly, the importance of designing public policies for reducing PM2.5 emissions lies in the seriousness of its implications both for the citizens and the government. Direct exposure of citizens to pollution imposes significant costs on the State. According to the Committee on the Medical Effects of Air Pollutants and its report Long-Term Exposure to Air Pollution: Effect on Mortality (COMEAP 2009), PM2.5 penetrates the human respiratory system causing hospitalization and premature deaths from both life-threatening and milder causes as allergic and asthmatic episodes or general malaise. Moreover, exposure to PM2.5 worsens the evolution of other diseases, from bronchitis to COVID-19 associated pathologies (Wu 2020).

These medical costs lead to high social and economic costs. Firstly, the harmful effects of air pollution increase medical costs significantly given the rise in hospitalizations and medical treatments. Secondly, the increase in the number of sickened people leads to greater labor absenteeism both in the short run because of minor problems (which lowers productivity) and in the long run because of aggravated chronic patients (which increase absenteeism still further). These productive and social welfare losses also impose serious costs on the State, the private sector and society. According to the OECD data, there is a relationship between PM2.5 levels and welfare losses from premature deaths, which also manifests itself in large losses in GDP

\footnotetext{
${ }^{5}$ For more detailed information on such processes, see DEFRA, 2013.
} 


\begin{tabular}{|c|c|c|c|}
\hline Measurement & Air pollutants & Major sources (anthropogenic) & $\begin{array}{l}\text { Major } \\
\text { impacts }\end{array}$ \\
\hline $\mathrm{CO}^{2}$ & $\mathrm{CO}^{2}$ & $\begin{array}{l}\text { Fossil fuels, industrial processes, land use } \\
\text { changes. }\end{array}$ & $\begin{array}{l}\text { Climate } \\
\text { Change }\end{array}$ \\
\hline \multirow{6}{*}{$\begin{array}{l}\text { PM2.5 } \\
\text { (Constituted by } \\
\text { liquid and solid } \\
\text { components in } \\
\text { different } \\
\text { proportions) }\end{array}$} & $\begin{array}{l}\text { Sulfuric Dioxide } \\
\left(\mathrm{SO}_{2}\right)\end{array}$ & $\begin{array}{c}\text { Power generation, industry, domestic and } \\
\text { commercial heating }\end{array}$ & \multirow{6}{*}{$\begin{array}{c}\text { Serious } \\
\text { health } \\
\text { problems. } \\
\text { Forest decline } \\
\text { and soil } \\
\text { acidification }\end{array}$} \\
\hline & $\begin{array}{c}\text { Nitrogen oxides } \\
\left(\mathrm{NO}_{\mathrm{x}}\right) \text { and ammonia } \\
\left(\mathrm{NH}_{3}\right)\end{array}$ & $\begin{array}{l}\text { Power generation and transport }\left(\mathrm{NO}_{\mathrm{x}}\right) \text {; } \\
\text { intensive agriculture }\left(\mathrm{NH}_{3}\right)\end{array}$ & \\
\hline & Acid deposition & Secondary pollutant formed from $\mathrm{SO}_{2}$ and $\mathrm{NO}_{2}$ & \\
\hline & Ozone $\left(\mathrm{O}_{3}\right)$ & $\begin{array}{c}\text { Secondary pollutant formed from } \\
\text { hydrocarbons and } \mathrm{NO}_{\mathrm{x}}\end{array}$ & \\
\hline & $\begin{array}{l}\text { Toxic metals (e.g } \\
\text { lead and cadmium) }\end{array}$ & Smelting industry; transport (lead) & \\
\hline & $\begin{array}{l}\text { Persistent organic } \\
\text { pollutants (POPs) }\end{array}$ & Industry, fuel combustion, pesticide use & \\
\hline
\end{tabular}

Table 1. Comparison between PM2.5 and $\mathrm{CO}^{2}$ composition, major sources, and consequences. $\mathrm{CO}^{2}$ is emitted directly into the atmosphere while PM2.5 is the combination of different polluting emissions. Source: DEFRA (2013), Ashmore (2013) and Gale et al. (2021

(Figure 1). As we can see, in some OECD countries, losses can be up to $9 \%$. With that level of human, social and economic loss, reducing PM2.5 emissions may play an important role in future environmental policies. Additionally, the short-run consequences of these emissions boost the urgency and importance of PM2.5 reduction.

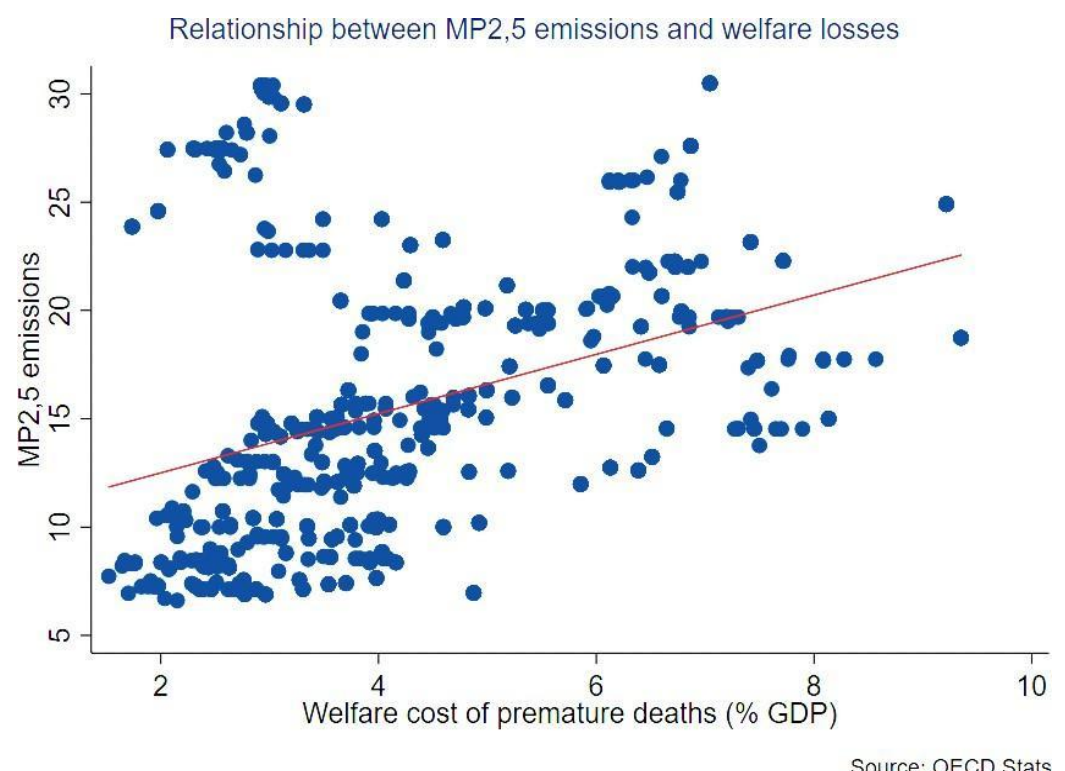

Figure 1: Relationship between PM2.5 emissions and costs in welfare associated with premature deaths as a percentage of GDP. Own creation. Data source: OECD stats.

iii Theory and logical mechanisms.

The theoretical framework of this paper proposes that not all environmental policies can result in an effective reduction of PM2.5 levels. This is based on three different arguments composed of several 
mechanisms. Through the following sections we show that citizens in countries with environmental innovation and economic incentives have lower exposure to air pollution as they create economic opportunities to make productive processes cheaper or advance development of technology. Meanwhile, citizens in countries with fiscal policies of taxes and limitations have higher exposure to air pollution. This is because the economic limitations are usually not high enough to impose severe costs and subsequent changes or, in the case of green taxes, are designed to reduce carbon rather than PM2.5 emissions.

\section{First mechanism: innovation and $R \& D$}

Government investment in R\&D and the promotion of innovative activities may be effective in achieving more emissions-efficient production systems, and in the dispersion of green technologies. Investments in R\&D can be used both for short-term productive improvements through financing and marketing incentives, as well as for long-term objectives in the field of industrial and energy renewal (Fischer and Newell 2008; Balsalobre et al. 2015; Alvarez-Herránz et al. 2017). The operationalization of this policy is mainly based on three processes, where one has direct effects on reducing citizens' exposure to pollution through innovation, and the others have indirect effects.

As with greenhouse gases, direct investment in innovation can lead to new technologies resulting in the reduction of citizens' exposure to pollution. This is because innovation subsidies encourage more efficient technologies in terms of energy expenditure and emissions. This results in cleaner technologies, which make use of non-polluting energy sources or that increase their energy efficiency, consuming less fuel and producing fewer polluting emissions for each input produced.

The first indirect mechanism is based on the lack of business profitability of some environmental technological innovations. Innovation and technology for reducing emissions of pollutants produces a positive externality, as it produces both knowledge and tools for air conservation as a common good. However, as it is not possible for companies to capture the total value of this investment in the market, implementing internal efficiency policies and reducing environmental degradation ends up being unprofitable (Jaffe, Newell and Stavins 2004). Since the value of these investments cannot be retained, companies have no incentive to invest in it, because they are not generating a real market advantage, and therefore innovation will not be directed to environmental objectives. Thus, the most efficient way to combat market inertia is through public investment (Bättig and Bernauer 2009), as it reduces the cost of technological production and increases innovation in those sectors where it is directed. Therefore, subsidies for renewable research and innovation help to minimize the effects of the main market problem of research in green technologies or energy improvement.

Finally, the second indirect mechanism deals with training problems for the techno-ecological transition. Government investments are often mostly focused on fundamental and applied research, which is necessary for the private sector to develop and apply technologies at a lower cost. Thus, government research, carried out largely from university centers and institutes, creates both knowledge and opportunities for new graduates and companies, increasing the qualified personnel needed to produce renewable or innovative technologies (World Bank 2008). In addition, it establishes the necessary connection between training and research centers and industry "through the support of researchers and graduates, public funding for research affects the economy's ability to generate and assimilate scientific advances, technological innovations and productive improvements" (OECD 2009).

Thus, public funding of innovation programs, the creation of incentives to companies to adopt new and more efficient technologies, and the establishment of university-industry connections could help reduce PM2.5 emissions. The first hypothesis is:

H1: "Countries whose government invests and promotes innovation through $R \& D$ have lower rates of citizens' exposure to air pollution" 
Second mechanism: economic incentives

Both the economic incentives for energy efficiency and renewable energy present double opportunities for the reduction of polluting emissions. Thus, it is possible to identify two mechanisms whereby energy efficiency and renewable energy economic incentive policies may lead to a decrease in citizens' exposure to air pollution.

The first mechanism refers to the direct effects of feed-in tariffs and green production certificates. Both "feed-in tariffs", that consist of the establishment of energetic regulation by means of renewable energy quotas which ensure a constant price of clean electricity for a specified period of time to consumers; and certificates of efficient production or energy efficiency, which ensures low energy production for each unit produced, have effects on reducing PM2.5 levels. The use of these economic incentives not only leads to innovation and technological transition, but also to an energy transition (Kim, Lee and Kim 2019). The use of feed-in tariffs reduces costs of renewable energy and makes it a risk-free bet for energy transition, as the latter's prices will remain constant during periods of between five and twenty years, reducing uncertainty and facilitating the investment needed. "Feed-in-tariffs" encourage private investment in innovative activities both domestically and internationally (Jaffe and Palmer 1997; Popp 2006). Additionally, certificates increase competitiveness and market acceptance, recognizing the quality of the products offered and providing commercial advantages (Ouillet 2002).

Furthermore, a positive regulation on renewable energy and energy efficiency increases their competitiveness against other highly polluting energy sources, such as fossil fuels (Kuik, Branger and Quirion 2019). It means, by giving economic benefits to clean energy sources, these policies decrease the marginal cost of renewable sources, making them cheaper.

Moreover, the second mechanism is based on the indirect effects of economic incentives. The promotion of the use of cleaner energy through economic incentives has its main indirect effect on induced innovation (Lanjouw and Mody 1996).
Induced innovation arises when one product becomes much more expensive in relative terms compared to another that could be its substitute. This induces innovation to lower costs. Economic incentives alter the opportunity cost of energy and production, leading companies, and individuals to adopt greener technologies, since clean energy is cheaper. In addition, when new technology is considered, the balance between its marginal cost and its marginal social benefits changes. That is, technology reduces the marginal cost of achieving some emission reduction (Goulder and Mathai 2000; OECD 2009). Induced innovation will aim at reducing emissions, increasing efficiency in the use of electricity, or creating new technologies that do not involve the forced use of certain energy sources such as fossil fuels. The second hypothesis is:

H2: "Countries whose government has established an economic incentive policy on energy efficiency and the promotion of renewable energy have lower rates of citizen exposure to air pollution"

\section{Third mechanism: fiscal policy}

Emissions taxes and limitations aim to discourage the use of polluting energy sources to enhance the use of clean energy and reduce the amount of gasses or emissions directly, but the approach may not be adequate for PM2.5 emission reduction for two reasons:

Firstly, the actual cost of emissions or penalties for non-compliance is rarely sufficiently high to lead to a real reduction of emissions (Montgomery and Smith 2007). In this way, the establishment of these taxes or limitations may give rise to effects contrary to expected results. If a particular business decides not to comply with the limitations, it will have to pay a fine, which, if it is not higher than the costs of adaptation or that the benefits of maintaining the polluting production, may not create sufficient incentive for reducing PM2.5 emissions or adopting cleaner technologies and energy sources. In other words, if the economic and market consequences of breaching the constraints are not greater than the profits obtained, the establishment of such policies may not have a positive effect, or even lead to an increase in emissions in the long run. 
Similarly, taxes on emissions of polluting gases or "green" taxes may seem a simple economic instrument but may have the opposite effect. Even with the establishment of such taxes, gas emissions may remain more cost-effective than adapting production with technology or new energy sources, and companies may not have incentives to reduce emissions. Moreover, if such a policy continues over time, it could become a fixed cost for companies. Fixed costs are predictable expenses that usually become part of a company's cost planning. In this case, green taxes may not have a strong enough coercive effect to reduce polluting emissions.

Moreover, most of these fiscal policies target $\mathrm{CO}^{2}$ emissions. Carbon emissions do not follow the same growth patterns of microparticle emissions because they are not created in the same way, so fiscal policy targets fail in accounting for the negative externality of citizens' exposure to air pollution.

Secondly, there may be a rebound effect--a phenomenon that occurs when incentives through fiscal policy have no effect on energy consumption and corporate emissions may detract from any gain made by fiscal policy (Grafton et al. 2014). The 'rebound effect' is produced by cheaper energy costs as a consequence of incentive policies, such as green energy subsidies, which are normally combined with tax policies. Green energy subsidies may nullify the effect of emissions taxes, because when they are higher than the taxes, they lower the average energy price, and do not produce significant changes in the reduction in energy consumption, or increase energy consumption because they foster lower economic costs per unit of production, since such a variation makes emission taxes or penalties for non-compliance with emission limits profitable (Grafton et al. 2014). This would produce a 'rebound effect' of emissions, and therefore a long-term increase in citizens' exposure to pollution. The third hypothesis is:

H3: "Countries whose government has established fiscal policies for emission reductions have higher rates of citizen exposure to air pollution"

\section{Data and Methods}

\section{i. Statistical analysis}

The following analysis seeks to examine which environmental policies are more effective in reducing citizens exposure to air pollution. These policies are grouped into three approaches: 1) support for innovation and technological development, 2) incentives for the use of renewable energy and energy efficiency, and 3) environmental fiscal policy. The study was carried out by observing the effects of such policies on thirty-three OECD member countries between 1990 and 2012 (Table 2). They have been selected since OECD countries have in common a significant level of polluting emissions, some degree of environmental regulation, as well as similar levels of industrialization and economic activity. In addition, the lack of data at the national level is particularly pronounced in environmental studies and the OECD database is one of the most exhaustive. The time frame of the samples is based on the publication of the First Evaluation Report (FAR) of the United Nations Intergovernmental Panel on Climate Change in 1990, which calls for reduction of air pollution in member countries and serves as a precedent for the creation of the United Nations Framework Convention on Climate Change (UNFCCC).

\section{ii. Model and variables}

This study presents a set of Ordinary Least Squares models $(\mathrm{OLS})^{6}$ with robust effects in which the observation unit is the country. The dependent variable studies citizens' exposure to air pollution, represented as the level of emissions of PM2.5 measured in micrograms per cubic meter $\left(\mu \mathrm{g} / \mathrm{m}^{3}\right)$.

This data has been obtained from the World Bank database (2020). The independent variables have been obtained from two sources: the databases of the World Bank (2020) and the OECD (2020). As seen in Table 3 , variables are divided into three categories: those related to innovation, those related to energy production and those related to fiscal policy on emissions.

\footnotetext{
${ }^{6}$ Ordinary Least Squares (OLS) is a statistical method for estimating the unknown parameters in a linear regression model.
} 


\begin{tabular}{|l|l|l|}
\hline \multicolumn{2}{|c|}{ Selected OECD countries } \\
\hline Germany & Estonia & Lithuania \\
\hline Australia & Finland & Luxembourg \\
\hline Austria & France & Norway \\
\hline Belgium & Greece & The Netherlands \\
\hline Canada & Hungary & Poland \\
\hline Chile & Ireland & Portugal \\
\hline Denmark & Iceland & United Kingdom \\
\hline Slovakia & Israel & Czech Republic \\
\hline Slovenia & Italy & Sweden \\
\hline Spain & Japan & Switzerland \\
\hline United States of America & Latvia & \\
\hline
\end{tabular}

Table 2. List of countries included in the statistical analysis. It includes all OECD members except Turkey and Colombia. This is motivated, in the first case, due to the lack of data on environmental issues, and in the second case, given Colombia's recent membership (2020)

\section{$R \& D$ and innovation variables}

The first category, which measures policies in terms of innovation and development, has two variables. First, government investment in R\&D is expressed in millions of dollars and with prices at the level of 2015. In this case, general government investment on innovation and development, not specifically innovation in environmental matters, was selected. According to the OECD (Nerwell 2007) it is not only green innovation that has positive effects on the environment, but almost any technological advance. General purpose technologies (GPTs), technologies that may have several uses within the economy, such as electric motors, semiconductors, steam machines, etc., and that also have an environmental use in terms of efficiency often support environmental goals (Nerwell 2007). Advances in GPTs are not counted as green technologies due their multiple uses, but by making processes more efficient, they help to reduce emissions. In addition, the development of such technologies increases the performance and subsequent benefits of truly environmental R\&D (Bresnahan and Trajtenber, 1995). Therefore, investment in general $R \& D$ is generally more accurate when accounting for how government investment affects PM2.5 emissions as it includes both purely green investment and GPTs. The data on green energies and GPTs have been obtained from the OECD database. Regarding the second variable that measures the promotion of innovative activities, collaboration between public universities and industry in research is used. It is measured using a World Bank index that measures the collaborative relationships between the two entities with one being the lowest or non-existent collaborative level and seven being the highest level of collaboration.

\section{Economic incentives variables}

In the second category, which measures regulation and incentives for renewable energy and energy efficiency, two variables are used. First, feed-in tariffs or energy quotas for renewable energy, which have been obtained from the OECD database and represent the value of quotas expressed in dollars per kilowatt hour $(\$ / \mathrm{kWh})$. Therefore, it is expected that the lower the quota value, the greater the incentives for technological and energy transformation and the lower the levels of PM2.5. Secondly, energy efficiency certificates are measured as the energy intensity ratio needed to achieve an efficient production certificate. This energy efficiency is measured as the energy units used to produce one unit of GDP (PPPS, at constant prices 2011). This variable has been obtained from the World Bank database and it is expected that, the lower the energy intensity ratio for obtaining certificates, the more efficient the production, and the fewer microparticles are emitted. Conversely, a higher ratio would mean higher levels of microparticle emissions. 


\begin{tabular}{|c|c|c|}
\hline Hypotheses & Variable & Operationalization \\
\hline \multirow{2}{*}{$\begin{array}{l}\text { HI: "Countries whose } \\
\text { government invests on } \\
\text { and promotes innovation } \\
\text { (R\&D) have lower } \\
\text { citizens' exposure rates to } \\
\text { air pollution" }\end{array}$} & $\begin{array}{l}\text { Var1: } \quad \text { Government } \\
\text { investment in R\&D }\end{array}$ & $\begin{array}{l}\text { Millions of dollars with prices at the level of } 2015 . \\
\text { Source: OECD stats. }\end{array}$ \\
\hline & $\begin{array}{lr}\text { Var2: } & \text { Collaboration } \\
\text { between } & \text { public } \\
\text { University and Industry. }\end{array}$ & $\begin{array}{l}\text { Index 1-7. } 1 \text { is non-existent and } 7 \text { being the } \\
\text { highest level of collaboration. Source: World Bank }\end{array}$ \\
\hline \multirow{2}{*}{$\begin{array}{l}\text { H2: "Countries whose } \\
\text { government has } \\
\text { established an incentive } \\
\text { policy on energy } \\
\text { efficiency and the } \\
\text { promotion of renewable } \\
\text { energy have lower rates } \\
\text { of citizens' exposure to air } \\
\text { pollution" }\end{array}$} & $\begin{array}{l}\text { Var3: Feed-in tariffs for } \\
\text { renewable energy (or } \\
\text { energy quotas) }\end{array}$ & $\begin{array}{l}\text { Value of the tariff expressed in dollars per kilowatt } \\
\text { hour. Source: OECD stats. }\end{array}$ \\
\hline & $\begin{array}{l}\text { Var4: Energy Efficiency } \\
\text { Certificates }\end{array}$ & $\begin{array}{l}\text { Energy intensity ratio needed to achieve an } \\
\text { efficient production certificate. Measured as the } \\
\text { energy units used to produce } 1 \text { unit of GDP (PPPS, } \\
\text { at constant prices 2011) } \\
\text { Source: World Bank }\end{array}$ \\
\hline \multirow{2}{*}{$\begin{array}{l}\text { H3: "Countries whose } \\
\text { government } \\
\text { established fiscal policies } \\
\text { for emission reduction } \\
\text { have higher rates of } \\
\text { citizens' exposure to air } \\
\text { pollution" }\end{array}$} & $\begin{array}{l}\text { Var5: Emissions taxes } \\
\text { (also called Green taxes) }\end{array}$ & $\begin{array}{l}\text { Percentage of the total taxes of the country that is } \\
\text { obtained from environmental taxes. Source: OECD } \\
\text { stats. }\end{array}$ \\
\hline & $\begin{array}{lr}\text { Var6: Limits } & \text { on } \\
\text { maximum } & \text { PM2.5 } \\
\text { emissions. } & \end{array}$ & $\begin{array}{l}\text { Index 1-7. 1- being the total absence of limits and } \\
\text { 7- the tax legislation with more restrictive limits. } \\
\text { Source: OECD stats. }\end{array}$ \\
\hline \multirow[t]{4}{*}{${ }^{*}$ Control variables } & Population & $\begin{array}{l}\text { Logarithm of total population in millions of } \\
\text { inhabitants. Source: OECD stats. }\end{array}$ \\
\hline & Wealth & $\begin{array}{l}\text { Logarithm of GDP per capita in millions of dollars. } \\
\text { Source: OECD stats. }\end{array}$ \\
\hline & Road traffic & $\begin{array}{l}\text { Road traffic in vehicles-km per thousand units of } \\
\text { GDP. Source: OECD stats. }\end{array}$ \\
\hline & Industrialization level & $\begin{array}{l}\text { Percentage of GDP generated by the industrial } \\
\text { sector. Source: OECD stats. }\end{array}$ \\
\hline *Dependent variable & $\begin{array}{l}\text { Citizens' exposure to air } \\
\text { pollution or PM2.5 }\end{array}$ & $\begin{array}{l}\text { Micrograms per cubic meter of air or } \mu \mathrm{g} / \mathrm{m}^{3} \text {. } \\
\text { Source: OECD stats. }\end{array}$ \\
\hline
\end{tabular}

Table 3. Hypotheses and variables, including sources and operationalization.

Fiscal policy variables

The third category, fiscal policy, encompasses two variables. First, the environmental tax rate also known as a "green tax," which is measured as the percentage of the country's total taxes obtained from environmental taxation. This variable has been obtained from the OECD database. The second variable in the category measures the limits on PM2.5 emissions through an index created by the OECD, with one being the total absence of limits and sanctions on emissions and seven being the most restrictive tax legislation.

\section{Control variables}

Finally, the control variables have been obtained entirely from the OECD database. These variables are based on prior scientific literature on PM2.5 (COMEAP 2010; DEFRA 2013). The first two variables are population and wealth and are based on the I-PAT model ${ }^{7}$. Population has been measured

7 The I-PAT model is a mathematical formula created in the 1970s by Barry Commoner, Paul R. Ehrlich, and John Holdren whose objective is to measure the impact of human activity on the environment. This formula interprets that the level of damage can be obtained from 
by millions of inhabitants, while wealth is measured by gross domestic product (GDP) per capita in

millions of dollars and at constant prices at the 2015 level. In both cases, they are computed as logarithms. Previously, a larger population has been linked to higher emissions, given the intensive use of resources that this implies. On the other hand, the literature states that wealth shows a U-shaped relationship with environmental pollution (Dinda 2004), since wealth is associated with more efficient industrial and economic growth processes, and therefore that depends to a lesser extent on the intensive use of resources. The other two control variables are the level of industrialization, measured as the percentage of GDP belonging to the industrial sector and road traffic, measured as road traffic in vehicle-km per thousand units of GDP. Both phenomena are considered by the scientific community to be between the main emitters of PM2.5 both directly and indirectly, given their intensive use of fossil fuels.

\section{Results}

Table 4 summarizes the main results of this study. This table shows the results of the six OLS estimates with robust standard errors. Each model analyzes the effect of a different independent variable on the dependent variable, which is citizens' exposure to air pollution expressed as PM2.5. Additionally, all models have the same control variables. The models are related in groups of two variables according to the three hypotheses studied, the first two models being part of the innovation hypothesis, the third and fourth corresponding to the assumption regarding economic incentive policy and the last two to fiscal policy.

\section{i. First hypothesis}

According to our data, there is a positive influence of the investment on research and university-industry collaboration to reduce PM2.5 levels. Thus, our first hypothesis seems correct. Both variables are statistically significant at $1 \%$. With respect to the first variable, government investment in innovation

the conjunction of the population of that territory, along with its wealth and available technology. For more information on the I-PAT model, see Ehrlich and Holdren (1971) And Chertow (2000). and development (R\&D) seems to relate to lower levels of PM2.5, although the effect is limited. For every million dollars invested in innovation, the rate of PM2.5 decreases by $0.0001 \mu \mathrm{g} / \mathrm{m} 3$. Normally, the usual rate of PM2.5 in the countries of the OECD is between 6 and $30 \mu \mathrm{g} / \mathrm{m}^{3}$ (see Table 5 for descriptive statistics). Therefore, the effect of innovation is not quite noticeable, even if significant. In addition, the $\mathrm{R}$ squared of the first model has an explanatory component of $38 \%$ of the variance, the lowest of all models.

On the other hand, research collaboration between industry and the public university seems to have an indirect and greater effect on reducing citizens' exposure to air pollution because of their effects on new technologies. An increase of a point out of seven in the system's ability to promote coordination of university institutions and companies in research and training indirectly means a decrease in PM2.5 levels of $2.7 \mu \mathrm{g} / \mathrm{m}^{3}$. The effect is therefore significant and greater than direct investments in innovation and $R \& D$, and with respect to $\mathrm{R}^{2}$ of the model, this has also a greater explanatory component, reaching $45 \%$ of the variance of MP2.5 levels.

As both variables are significant and have inverse relationships with the microparticles, our data suggests the first hypothesis is correct. Countries whose governments invest more on $R \& D$ and promote it in the education and industrial system have lower rates of citizens' exposure to air pollution. This coincides with previous literature on $\mathrm{CO}^{2}$ and other greenhouse gases (Balsalobre et al. 2015; Alvarez-Herránz et al. 2017; Popp 2006). It is surprising that previous literature (Fisher and Newell 2008) has given higher importance to the effect of R\&D investments on air pollution reduction than our data seems to indicate. This may indicate the variance of results between $\mathrm{CO}^{2}$ and PM2.5 emissions that motivated this paper.

This difference between the previous literature and our results may be explained for two fundamental reasons: first, that the investment in $R \& D$ is usually targeted through objectives based on $\mathrm{CO}^{2}$ emissions. Most technological innovation projects for emission reduction or energy efficiency set $\mathrm{CO}^{2}$-based targets, as it is the most common measure to evaluate the 


\begin{tabular}{|c|c|c|c|c|c|c|}
\hline \multicolumn{7}{|c|}{ tatistical analysis results } \\
\hline & (M1) & (M2) & (M3) & (M4) & (M5) & (M6) \\
\hline & Innovation & Innovation & $\begin{array}{l}\text { Incentive } \\
\text { policy }\end{array}$ & $\begin{array}{l}\text { Incentive } \\
\text { policy }\end{array}$ & $\begin{array}{l}\text { Fiscal } \\
\text { policy }\end{array}$ & Fiscal policy \\
\hline Wealth (log) & $\begin{array}{c}-5.5099^{* * *} \\
(0.5454) \\
\end{array}$ & $\begin{array}{c}-3.1333^{* * *} \\
(0.7090) \\
\end{array}$ & $\begin{array}{c}-7.3204^{* * *} \\
(0.5036)\end{array}$ & $\begin{array}{c}-7.0994^{* * *} \\
(0.4631) \\
\end{array}$ & $\begin{array}{c}-5.5624^{* * *} \\
(0.5320) \\
\end{array}$ & $\begin{array}{c}-11.7273^{* * *} \\
(0.5762) \\
\end{array}$ \\
\hline Population (log) & $\begin{array}{l}1.4855^{* * *} \\
(0.1620)\end{array}$ & $\begin{array}{l}0.9659^{* * *} \\
(0.1125)\end{array}$ & $\begin{array}{l}0.5132^{* * *} \\
(0.1276)\end{array}$ & $\begin{array}{l}1.2978^{* * *} \\
(0.1270)\end{array}$ & $\begin{array}{l}1.1508^{* * *} \\
(0.1262)\end{array}$ & $\begin{array}{l}0.5660^{* * *} \\
(0.1325)\end{array}$ \\
\hline $\begin{array}{c}\text { Industrialization } \\
\text { Level }\end{array}$ & $\begin{array}{l}0.1913^{* * *} \\
(0.0478)\end{array}$ & $\begin{array}{l}0.3134^{* * *} \\
(0.0459)\end{array}$ & $\begin{array}{l}0.2920^{* * *} \\
(0.0465)\end{array}$ & $\begin{array}{l}0.2724^{* * *} \\
(0.0460)\end{array}$ & $\begin{array}{l}0.2097^{* * *} \\
(0.0447)\end{array}$ & $\begin{array}{l}0.2874^{* * *} \\
(0.0481)\end{array}$ \\
\hline Road traffic & $\begin{array}{c}0.0025 \\
(0.0013) \\
\end{array}$ & $\begin{array}{c}0.0027^{*} \\
(0.0012)\end{array}$ & $\begin{array}{c}0.0031^{*} \\
(0.0012)\end{array}$ & $\begin{array}{l}0.0045^{* * *} \\
(0.0013)\end{array}$ & $\begin{array}{c}0.0015 \\
(0.0012) \\
\end{array}$ & $\begin{array}{l}0.0075^{* * *} \\
(0.0011)\end{array}$ \\
\hline$R \& D$ invest. & $\begin{array}{l}-0.0001^{* * *} \\
(0.0000)\end{array}$ & & & & & \\
\hline $\begin{array}{c}\text { Uni-Industry } \\
\text { Collaboration }\end{array}$ & & $\begin{array}{l}-2.7553^{* * *} \\
(0.3043)\end{array}$ & & & & \\
\hline $\begin{array}{c}\text { Certificates } \\
\text { (Energy } \\
\text { efficiency) }\end{array}$ & & & $\begin{array}{c}-0.8043^{* * *} \\
(0.1092)\end{array}$ & & & \\
\hline $\begin{array}{c}\text { Feed-in tariffs } \\
\text { (Renewable } \\
\text { energy) }\end{array}$ & & & & $\begin{array}{l}8.6432^{* * *} \\
(6.6667)\end{array}$ & & \\
\hline Green tax & & & & & $\begin{array}{l}0.8389^{* * *} \\
(0.1011)\end{array}$ & \\
\hline $\begin{array}{c}\text { PM2.5 emission } \\
\text { limit }\end{array}$ & & & & & & $\begin{array}{l}1.4190^{* * *} \\
(0.2115)\end{array}$ \\
\hline _cons & $\begin{array}{c}53.5750^{* * *} \\
(6.3703) \\
\end{array}$ & $\begin{array}{c}42.6557^{* * *} \\
(7.0552) \\
\end{array}$ & $\begin{array}{c}82.7825^{* * *} \\
(5.9934) \\
\end{array}$ & $\begin{array}{c}67.8088^{* * *} \\
(5.8445) \\
\end{array}$ & $\begin{array}{c}50.3336^{* * *} \\
(6.2454) \\
\end{array}$ & $\begin{array}{c}120.6048^{* * *} \\
(6.8238) \\
\end{array}$ \\
\hline$N$ & 641 & 656 & 656 & 656 & 656 & 488 \\
\hline$R^{2}$ & 0.3795 & 0.4492 & 0.4390 & 0.4425 & 0.4429 & 0.5435 \\
\hline$F$ & & & & & & \\
\hline$L I$ & -1933.6548 & -1949.0021 & -1955.0217 & -1952.9910 & -1952.7100 & -1362.9614 \\
\hline
\end{tabular}

Standard errors in parentheses ${ }^{*} p<0.05,{ }^{* *} p<0.01,{ }^{* * *} p<0.001$

Table 4: Effectiveness of public environmental policies in reducing PM2.5 levels.

Descriptive statistics

\begin{tabular}{|l|l|l|l|l|l|}
\hline Variable & Obs. & Mean & Std. Dev. & Min & Max \\
\hline PM2.5 & 805 & 15.52 & 6.465 & 6.613 & 30.488 \\
\hline Investment in R\&D & 766 & 9176.373 & 21282.13 & 40.172 & 151000 \\
\hline $\begin{array}{l}\text { Collaboration Uni- } \\
\text { Industry }\end{array}$ & 805 & 4.552 & .801 & 2.548 & 5.968 \\
\hline $\begin{array}{l}\text { Feed-in tariffs } \\
\text { (Renewable } \\
\text { efficiency) }\end{array}$ & 805 & .01 & .02 & 0 & .174 \\
\hline
\end{tabular}




\begin{tabular}{|l|l|l|l|l|l|}
\hline $\begin{array}{l}\text { Certificates } \\
\text { (Energy efficiency) }\end{array}$ & 805 & 5.964 & 2.574 & 2.457 & 19.218 \\
\hline Green tax & 805 & 7.231 & 2.224 & .092 & 14.762 \\
\hline PM2.5 limits & 598 & 1.406 & 1.229 & 0 & 6 \\
\hline Population & 785 & 9.367 & 1.524 & 5.54 & 12.658 \\
\hline Wealth & 779 & 10.361 & .446 & 9.085 & 11.588 \\
\hline Industrialization & 711 & 26.333 & 5.083 & 10.671 & 41.107 \\
\hline Road traffic & 744 & 249.202 & 168.565 & 4.972 & 733.377 \\
\hline
\end{tabular}

Table 5: Descriptive Statistics of our main variables.

contribution to climate change. As such, this could lead to the effects of innovation having a minor impact on other gases or substances such as PM2.5. Second, as we can see in the third model (M3) on incentive policy, energy efficiency policies do not seem to have a real influence on PM2.5 levels, which would lead to the impact of innovation also being reduced. Much of $R \& D$ aims to make production processes more efficient, especially when it comes to general purpose technologies (GPTs), and energy efficiency is largely a consequence of these innovative processes. If promoting energy efficiency does not produce less PM2.5 emissions (Model 3), investment in research that promotes energy efficiency would also have a limited effect. Thus, the effectiveness of innovation as a whole will be reduced, being limited to innovation with other targets, such as renewable energy.

Moreover, the lack of effectiveness of direct investments in innovation could be related to the theory put forward by Schneider and Goulder (1997) whereby technology subsidies and investments on technology are not translated into lower emissions if they are not combined with economic and fiscal incentives for implementation. Further studies would be needed to address the combination of these environmental policies to understand how this mechanism works in terms of PM2.5.

\section{Second hypothesis}

We can neither accept nor reject the second hypothesis. First, with reference to the certificates of energy efficiency, a lower energy intensity ratio for certificates (meaning higher energy efficiency) does not appear to be associated with a decrease in the levels of exposure to air pollution, if not quite the opposite. However, better energy efficiency was expected to be linked to lower levels of PM2.5 and therefore a positive relationship between the ratio and the level of citizen exposure to air pollution. Contrary to expectations, a one-point decrease in the energy efficiency ratio, in a ratio ranging from two to twenty points, leads to an increase of $0.8 \mu \mathrm{g} / \mathrm{m}^{3}$ in PM2.5 emission levels. This would imply that within the various economic incentives, the emission of production certificates with energy efficiency is not an effective policy when referring to PM2.5 emissions. This data supports the thesis of authors such as Hart (2008) and Bossetti et al. (2009). Perhaps these economic incentives were not strong enough to stabilize or decrease the levels of emissions of polluting gases on their own, due, among others, to phenomena such as the rebound effect and the lowering of energy prices advocated by Grafton et al. (2014).

On the other hand, the "feed-in-tariffs" model (M4) seems to support the hypothesis that raises the positive effectiveness of economic incentives on PM2.5 emissions, which match with the previous literature (Lanjouw and Mody 1996; Jaffe and Palmer 1997; Goulder and Mathai 2000; Popp 2006; Johnstone and Hascic 2009). According to Model 4, the promotion of renewable energy through feed-in tariffs or energy quotas appears to have a very significant influence on the levels of citizens' exposure to air pollution. Model 4 shows that low energy quotas, involving a low price of renewable energy, would lead to lower PM2.5 levels. The 
positive ratio between the value of quotas and the exposure levels means that, for each increase of one dollar per kWh in the price of renewable energy set by quotas, PM2.5 levels would increase by up to 8.64 points. Conversely, a drop of one dollar per $\mathrm{kWh}$ would reduce PM2.5 levels by up to $8.64 \mu \mathrm{g} / \mathrm{m}^{3}$ Since these typically range from 3 to $30 \mu \mathrm{g} / \mathrm{m}^{3}$, a policy of energy quotas in renewable energy seems to be a very effective measure for reducing citizens' exposure to air pollution and its subsequent consequences. This could be caused by a change in the opportunity cost of renewables and pollutants. The change in the comparative difference would lead companies to adopt renewable energy with feed-in tariffs to have lower and more stable energy prices. At the same time, it produces a drop in the most polluting gas sources, especially fossil fuels.

Therefore, the second hypothesis, which states that countries whose governments have established an incentive policy on energy efficiency and the promotion of renewable energy have lower rates of citizens' exposure to air pollution, has only partial support. While energy efficiency certificates in production seem to even increase PM2.5 levels, energy quotas for renewable energy not only have a strong reducing effect on emissions from such microparticles but appear to have the strongest effect among all other environmental public policies. These two models have explanatory levels of $38 \%$ and $45 \%$ respectively, with the model of policies relating to energy quotas for renewable energy being more explanatory.

\section{Third hypothesis}

Finally, the last two models, M5 and M6, correspond to the third hypothesis, concerning the fiscal incentives policies. In the specific case of emission taxes and the allowed PM2.5. limits, both variables show contrary effects to the policy objectives. First, with respect to taxes, a $1 \%$ increase in the percentage of the country's total taxes from environmental taxes leads to an increase in PM2.5.5 levels of $0.8 \mu \mathrm{g} / \mathrm{m}^{3}$.

Second, with respect to the limits on PM2.5 emissions, their multiplier effect appears to be even greater. For each increase in position in the OECD index that measures the severity of these limitations, exposure to air pollution appears to rise by 1.4 $\mu \mathrm{g} / \mathrm{m}^{3}$. This would imply that greater restrictions on the emission of microparticles do not appear to be effective in reduction and may even be generating effects contrary to the stated objectives. The same happens in the case of taxes. Not only do they not reduce PM2.5 emissions, they may in fact increase them. This result is consistent with previous reasoning and can be explained for various reasons. First, the penalties and prices of limitations and taxes are usually not high enough to discourage the use of polluting resources (Montgomery and Smith 2007). Second, the rebound effect (Grafton et al. 2014) produced by other energy conversion policies, such as economic incentive policies, may play a role. The effect of those policies on the economy can offset the pressure exerted by fiscal policy on the price of energy and leave it unchanged, so the conjunction of the two can nullify the effect of the fiscal policies.

Therefore, the data supports the third hypothesis, that countries whose governments have established fiscal policies for reducing emissions have higher rates of citizens' exposure to air pollution. Moreover, the models have a high explanatory power, explaining the $44 \%$ and $54 \%$ of the variance of the dependent variable respectively, while the latter model, concerning the limits on emissions, enjoys the highest level of significance among the six models.

\section{Outcomes and policy recommendations}

Finally, we can conclude that while the data supports the first and third hypotheses, the data is unclear with respect to the second hypothesis. This means that there is evidence that state investments in $R \& D$ and the promotion of innovative activities have a reducing effect on citizens' exposure to air pollution. Similarly, data also shows that policies of feed-in tariffs for renewable energy have the strongest emission-reducing effects. On the other hand, the establishment of taxes and limitations on polluting emissions does not affect PM2.5 levels (even potentially resulting in an increase) while the efficient production certificates also produce negative results.

The results allow us to identify some good practices when designing environmental public policy, even if 
we should also bear in mind that there is no one-size-fits-all formula. Policymakers should adjust their policy strategy according to the nature and specific characteristics of their territory. However, some general lessons and recommendations can be drawn from this study:

- Comparing the effectiveness of different policies for $\mathrm{CO}^{2}$ emissions reduction on those for PM2.5 reduction, we can conclude that environmental policies have different outcomes regarding PM2.5 and $\mathrm{CO}^{2}$ levels. This implies that there is a clear necessity for an individualized approach for reducing PM2.5. Both $\mathrm{CO}^{2}$ and PM2.5 must be considered for policymakers as independent variables.

- Direct investment in innovation and R\&D has a limited effect on PM2.5 levels reduction, while investment in research collaborations between the public university and the industry seems to be more positive for the reduction of microparticles. Consequently, when designing green technology investment policies, it seems more effective in terms of microparticle reduction to potentiate research partnerships between public universities and private companies than to invest directly in certain technologies, since research consortia may facilitate the green technology transmission and further assimilation by companies.

- As other authors have suggested, "green production" certificates do not have a strong enough effect on emission reduction to impact PM2.5 levels. Consequently, even if these certificates may foster greener behaviors - that in the long run may have positive effects on emissions levels - the emission of green production certificates is not an effective policy when aiming at PM2.5 levels reduction.

- According to our study, feed-in tariffs (or energy quotas) seem to be the most effective policy when aiming to reduce exposure to air pollution and its subsequent consequences. This is likely because feed-in tariffs ensure a constant price of clean electricity for a specified period of time to consumers, making renewable energy a cheaper and risk-free bet for energy transition.

- It does not seem adequate to establish emission taxes or limits to PM2.5 emissions. All fiscal policies seem to be ineffective when aiming to reduce microparticles levels, even showing contrary effects to those intended. Normally, this effect is attributed to the economic weakness of the sanctions and the distorting effects that the intersection of fiscal and economic incentives policies may have.

\section{Limitations}

Previous studies on PM2.5 emissions reduction policies are quite rare and mostly approached as case studies. The results presented in this study need to be interpreted carefully. The results are preliminary and more and deeper investigation is needed.

Moreover, there are limitations to be considered in interpretation and application of findings. First, there is a lack of data on environmental policies at the national level and limited methodologies in comparing different policies in a cross-national way. Second, we can identify a certain degree of endogeneity between some variables, especially those related to induced innovation, although it does not seem strong enough to affect the model, but still must be considered.

\section{Further research}

Finally, further lines of investigation should evaluate the results of PM2.5 levels resulting from different sets or portfolios of these combined policies, since the joint implementation of these combined policies can alter key elements, such as the value of resources, and lead to different results. In addition, more empirical evidence is needed to demonstrate the relationship between environmental policies and citizens' exposure to air pollution, while this preliminary line of investigation needs to be deepened from different perspectives, such as using a regional approach to study the relationship between environmental policies and PM2.5 in rural and urban environments separately. 


\section{Conclusion}

i. Importance of PM2.5 studies for environmental policy

This study investigates the effectiveness of different environmental policies to reduce citizens' exposure to air pollution through an OLS model. It is motivated by the necessity of broadening the studies on emission reduction, as well as of reducing the consequences that PM2.5 exposure entails for the states and their populations. This study demonstrates that not all environmental policies are effective for the reduction of PM2.5, and that, among them, investment policies in R\&D show positive but limited results, fiscal policies have increasing and ineffective effects, and among economic incentive policies, only feed-in tariffs present an effective opportunity to reduce PM2.5 emissions.

These results are important in achieving cleaner environments, and in avoiding the human, social and economic consequences of pollution. These

\section{References}

Alvarez-Herranz, Agustin, Daniel Balsalobre-Lorente, Muhammad Shahbaz, and José María Cantos. 2017. "Energy Innovation And Renewable Energy Consumption In The Correction Of Air Pollution Levels". Energy $\quad$ Policy 105: 386-397. doi:10.1016/i.enpol.2017.03.009.

Ashmore, Mike. 2013. "Air Pollution. Encyclopedia of Biodiversity (Second Edition)". Academic Press: 136-147.

doi.org/10.1016/B978-0-12-384719-5.00283-5.

Balsalobre, Daniel, Agustín Álvarez, and José María Cantos. 2014. "Public Budgets For Energy RD\&D And The Effects On Energy Intensity And Pollution Levels". Environmental Science And Pollution Research 22 (7): 4881-4892.

doi:10.1007/s11356-014-3121-3.

Bättig, Michèle B., and Thomas Bernauer. 2009. "National Institutions And Global Public Goods: Are Democracies More Cooperative In Climate Change Policy?". International Organization 63 281-308. doi:10.1017/s0020818309090092.

Bilgili, Faik, Emrah Koçak, Ümit Bulut, and Sevda Kuşkaya. 2017. "Can Biomass Energy Be An Efficient Policy Tool For Sustainable Development?". Renewable And Sustainable Energy Reviews 71: 830-845. doi:10.1016/i.rser.2016.12.109. consequences include profound human and productivity losses, as well as they impose high costs on health and social security services. Those consequences represent strong and important incentives for the governments to design emissions legislation by using PM2.5 measurement, and for that, an analysis on the effectiveness of environmental policies is needed.

Consequently, this work contributes to an empirical study on environmental policies on polluting emissions, focusing not on the classical scope of $\mathrm{CO}^{2}$ or greenhouse gas emissions, but on PM2.5, which represents the added challenge of citizens' exposure to pollution. Consequently, this study diversifies the field by going beyond climate change's traditional policies research, making it a practical opportunity for policymakers to choose the most effective approach.

Bilgili, Faik, Emrah Koçak, Ümit Bulut, and M. Nedim Sualp. 2016. "How Did The US Economy React To Shale Gas Production Revolution? An Advanced Time Series Approach". Energy 116: 963-977. doi:10.1016/i.energy.2016.10.056.

Bosetti, Valentina, Carlo Carraro, Romain Duval, Alessandra Sgobbi, and Massimo Tavoni. 2009. "The Role Of R\&D And Technology Diffusion In Climate Change Mitigation: New Perspectives Using The Witch Model". SSRN Electronic Journal. doi:10.2139/ssrn.1397076.

Bresnahan, Timothy F., and M. Trajtenberg. 1995. "General Purpose Technologies 'Engines of Growth'?". Journal of Econometrics 65 (1): 83-108. doi:10.1016/0304-4076(94)01598-t.

Cheng, Zhonghua, Lianshui Li, and Jun Liu. 2017. "The Emissions Reduction Effect And Technical Progress Effect Of Environmental Regulation Policy Tools". Journal of Cleaner Production 149: 191-205. doi:10.1016/i.jclepro.2017.02.105.

Chertow, Marian R. 2000. "The IPAT Equation And Its Variants".Journal of Industrial Ecology 4 (4): 13-29. doi:10.1162/10881980052541927. 
Das, Trishna, Venkat Krishnan, and James D. McCalley. 2015. "Assessing The Benefits And Economics Of Bulk Energy Storage Technologies In The Power Grid". Applied Energy 139: 104-118. doi:10.1016/i.apenergy.2014.11.017.

DEFRA. 2013. "Report: Fine Particulate Matter $\left(\mathrm{PM}_{2.5}\right)$ In The United Kingdom", London: Department for Environmental Food and Rural Affairs. https://uk-air.defra.gov.uk/assets/documents/re ports/cat11/1212141150 AOEG Fine Particulate Matter in the UK.pdf

Dinda, Soumyananda. 2004. "Environmental Kuznets Curve Hypothesis: A Survey". Ecological Economics 49 (4): 431-455. doi:10.1016/i.ecolecon.2004.02.011.

Ehrlich, P. R., and J. P. Holdren. 1971. "Impact Of Population Growth". Science 171 (3977): 1212-1217. doi:10.1126/science.171.3977.1212.

Fernández Fernández, Y., M.A. Fernández López, and B. Olmedillas Blanco. 2018. "Innovation For Sustainability: The Impact Of R\&D Spending On CO2 Emissions".Journal of Cleaner Production 172: 3459-3467. doi:10.1016/i.jclepro.2017.11.001.

Fischer, Carolyn, and Richard G. Newell. 2008. "Environmental And Technology Policies For Climate Mitigation". Journal of Environmental Economics And Management 55 (2): 142-162. doi:10.1016/i.jeem.2007.11.001.

Gale, John, John Bradshaw, Amit Garg, Dario Gomez, Hans-Holger Rogner, Zhenlin Chen, Dale Simbeck, and Robert Willians. 2021. "Sources Of CO2 IPCC". Ipcc.Ch.

https://www.ipcc.ch/report/carbon-dioxide-capt ure-and-storage/sources-of-co2/.

Garrone, Paola, and Luca Grilli. 2010. "Is There A Relationship Between Public Expenditures In Energy R\&D And Carbon Emissions Per GDP? An Empirical Investigation". Energy Policy 38 (10): 5600-5613.

doi:10.1016/i.enpol.2010.04.057.

Gerlagh, Reyer, and Bob van der Zwaan. 2006. "Options And Instruments For A Deep Cut In $\mathrm{CO} 2$ Emissions: Carbon Dioxide Capture Or Renewables, Taxes Or Subsidies?". The Energy Journal 27 (3). doi:10.5547/issn0195-6574-ej-vol27-no3-3.

Goulder, Lawrence H., and Koshy Mathai. 2000. "Optimal CO2 Abatement In The Presence of Induced Technological Change". Journal of Environmental Economics And Management 39 (1): 1-38. doi:10.1006/ieem.1999.1089.

Goulder, Lawrence H. 2002. "Environmental Policy Making in Economies with Prior Tax Distortions". Cheltenham: Edward Elgar.
Grafton, R. Quentin, Tom Kompas, Ngo Van Long, and Hang To. 2014. "US Biofuels Subsidies And CO2 Emissions: An Empirical Test For A Weak And A Strong Green Paradox". Energy Policy 68: 550-555. doi:10.1016/i.enpol.2013.11.006.

Harrison, Roy M., Chiara Giorio, David C.S. Beddows, and Manuel Dall'Osto. 2010. "Size Distribution of Airborne Particles Controls Outcome of Epidemiological Studies". Science of The Total $\begin{array}{llll}\text { Environment } 409 & \text { (2): } 289-293 .\end{array}$ doi:10.1016/i.scitotenv.2010.09.043.

Hart, Rob. 2008. "The Timing Of Taxes On CO2 Emissions When Technological Change Is Endogenous". Journal of Environmental Economics And Management 55 (2): 194-212.

doi:10.1016/i.jeem.2007.06.004.

Haščič, Ivan, Johnstone, Nick, Watson, Fleur and Kaminker, Christopher. 2010. "Climate Policy and Technological Innovation and Transfer: An Overview of Trends and Recent Empirical Results". OECD Environment Working Papers, No. 30. Paris: OECD Publishing. doi: $10.1787 / 5 \mathrm{~km} 33 \mathrm{bnggcd} 0$-en

Heyes, Anthony, and Sandeep Kapur. 2011. "Regulatory Attitudes And Environmental Innovation In A Model Combining Internal And External R\&D". Journal of Environmental Economics And $\begin{array}{llll}\text { Management } & 61 & \text { (3): } & 327-340 .\end{array}$ doi:10.1016/i.jeem.2010.12.003.

International Energy Agency. 2020. "IEA Energy Technology RD\&D Statistics" Data and Statistics IAE. https://www.iea.org/data-and-statistics/charts

Johnstone, Nick, Ivan Haščič, Julie Poirier, Marion Hemar, and Christian Michel. 2012. "Environmental Policy Stringency And Technological Innovation: Evidence From Survey Data And Patent Counts". Applied Economics 44 (17): 2157-2170. doi:10.1080/00036846.2011.560110.

Jaffe, Adam B., and Karen Palmer. 1997. "Environmental Regulation And Innovation: A Panel Data Study". Review of Economics And Statistics 79 (4): 610-619. doi:10.1162/003465397557196.

Jaffe, Adam B., Richard G. Newell, and Robert N. Stavins. 2000. "Technological Change And The Environment". SSRN Electronic Journal. doi:10.2139/ssrn.252927.

Kim, Seoyong, Jae Lee, and Donggeun Kim. 2019. "Searching For The Next New Energy In Energy Transition: Comparing The Impacts Of Economic Incentives On Local Acceptance Of Fossil Fuels, Renewable, And Nuclear Energies". Sustainability $11 \quad$ (7): 2037. doi:10.3390/su11072037. 
Koçak, Emrah, and Zübeyde Şentürk Ulucak. 2019. "The Effect Of Energy R\&D Expenditures On CO2 Emission Reduction: Estimation Of The STIRPAT Model For OECD Countries". Environmental Science And Pollution Research 26 (14): 14328-14338. doi:10.1007/s11356-019-04712-2.

Kuik, Onno, Frédéric Branger, and Philippe Quirion. 2019. "Competitive Advantage In The Renewable Energy Industry: Evidence From A Gravity Model". Renewable Energy 131: 472-481. doi:10.1016/i.renene.2018.07.046.

Lanjouw, Jean Olson, and Ashoka Mody. 1996. "Innovation And The International Diffusion Of Environmentally Responsive Technology". Research Policy 25 (4): 549-571. doi:10.1016/0048-7333(95)00853-5.

Montgomery, David W. and Smith, Anne. 2007. "Price, Quantity, And Technology Strategies For Climate Change Policy." Chapter. In Human-Induced Climate Change: An Interdisciplinary Assessment, edited by Michael E. Schlesinger, Haroon S. Kheshgi, Joel Smith, Francisco C. de la Chesnaye, John M. Reilly, Tom Wilson, and Charles Kolstad, 328-42. Cambridge: Cambridge University Press. doi:10.1017/CB09780511619472.032.

Newell, Richard. 2009. "Literature Review of Recent Trends and Future Prospects for Innovation in Climate Change Mitigation". OECD Environment Working Papers №9. Paris: OECD Publishing. doi: $10.1787 / 218688342302$

Newell, Richard. 2010. "The Role Of Markets And Policies In Delivering Innovation For Climate Change Mitigation". Oxford Review Of Economic Policy 26 (2): 253-269. doi:10.1093/oxrep/grq009.
Popp, David. 2006. "Comparison Of Climate Policies In The ENTICE-BR Model". The Energy Journal SI2006 (01).

doi:10.5547/issn0195-6574-ej-volsi2006-nosi1$\underline{7}$.

Ouillet, Laetitia. 2003. "Green energy in Europe: Selling green energy with green certificates". Elsevier

(2):52-55.

https://doi.org/10.1016/S1471-0846(02)80032

The Committee on the Medical Effects of Air Pollutants (COMEAP). 2010. "The Mortality Effects of Long-Term Exposure to Particulate Air Pollution in the United Kingdom". London: Department of Health.

https://assets.publishing.service.gov.uk/governm ent/uploads/system/uploads/attachment data/f ile/304641/COMEAP mortality effects of long $t$ erm exposure.pdf

Schneider, Stephen, and Goulder, Lawrence. 1997. "Achieving Low-cost Emissions Targets" Nature 389(2): 13-14. doi.org/10.1038/37861

World Bank. 2008. "The World Bank Annual Report 2008: Year in Review". World Bank Group. doi:10.1126/sciadv.abd4049. http://documents.worldbank.org/curated/en/45 2391468323718231/The-World-Bank-annual-re port-2008-year-in-review

World Bank. 2020. "Databank | The World Bank". Databank.Worldbank.Org. https://databank.worldbank.org/home.aspx.

$\mathrm{Wu}$, Xiao, Rachel Nethery, Benjamin Sabath, Danielle Braun, and Francesca Dominici. 2020. "Air Pollution And COVID-19 Mortality In The United States: Strengths And Limitations of An Ecological Regression Analysis". Science Advances 6(45).

Leticia Abarca Velencoso is a political scientist with strong focus on Regional, Rural and Climate international policy. She studied a dual Bachelor in Political Science and International Studies in the Carlos III of Madrid University, spending several periods in other universities as Riga Stradins University and the Pontifical Catholic University of Rio de Janeiro. Due to her academic background, she received the Award of Academic Excellence of the Community of Madrid in 2020. Additionally, she has also written several articles on international issues related to environmental policy and she is currently studying a Master on Economy of the European Union at UNED. In the last year, she also trained on European project management in the University of Valencia and works as a Project Manager conducting programs on sustainable development for rural and green protected areas.

\section{Acknowledgements}

The author would like to first thanks to the Carlos III University's professors that inspired her during the university period and that have contributed with their expertise to her academic pathway. Additionally, she would like to thank her parents for their tireless support and Willian for sharing with her his passion for science. 